ТЕОРЕТИЧНІ ПРОБЛЕМИ РОЗВИТКУ НАЦІОНАЛЬНОЇ ЕКОНОМІКИ

UDC 005.334-047.44:338.4

DOI: $10.25140 / 2411-5215-2018-2(14)-24-31$

Olena Shyshkina, Olga Kalchenko

\title{
METHODOLOGICAL PRINCIPLES OF THE ANALYSIS AND RISK ASSESSMENT OF THE ENVIRONMENT IN THE PROCESS OF PLANNING THE DEVELOPMENT OF REAL ECONOMY SECTOR SUBJECTS
}

Олена Шишкіна, Ольга Кальченко

\section{МЕТОДОЛОГІЧНІ ЗАСАДИ АНАЛІЗУ Й ОЦІНКИ РИЗИК-СЕРЕДОВИЩА В ПРОЦЕСІ ПЛАНУВАННЯ РОЗВИТКУ СУБ'СКТІВ РЕАЛЬНОГО СЕКТОРУ ЕКОНОМКИ}

\author{
Елена Шишкина, Ольга Кальченко
}

\section{МЕТОДОЛОГИЧЕСКИЕ ОСНОВЫ АНАЛИЗА И ОЦЕНКИ РИСК-СРЕДЫ В ПРОЦЕССЕ ПЛАНИРОВАНИЯ РАЗВИТИЯ СУБЪЕКТОВ РЕАЛЬНОГО СЕКТОРА ЭКОНОМИКИ}

In the article the essence, content and components of the planning of development of the subjects of the real sector of the economy are examined, the place and role of the analysis and assessment of the risk environment in the process of development planning are determined, the basic methods of its analysis and evaluation are systematized. The study leads to the conclusion about the need for analysis and assessment of risk environment, which contributes to improving the effectiveness of the implementation of strategic and tactical plans in the process of planning the development of entities in the real sector of the economy.

Keywords: development planning; risk environment; real sector of economy; methods of analysis; formalized methods; non-formalized methods.

Fig.: 2. References: 6.

У статті досліджено сутність, зміст та складові елементи планування розвитку суб'єктів реального сектору економіки, визначено місце та роль аналізу й оиінки ризик-середовища в процесі планування розвитку, систематизовано основні методи його аналізу й оцінки. Проведене дослідження дає змогу дійти висновків про необхідність аналізу й оцінки ризик-середовища, щь сприяе підвищенню ефективності реалізації стратегічних і тактичних планів у процесі планування розвитку суб'єктів реального сектору економіки.

Ключові слова: планування розвитку; ризик-середовище; реальний сектор економіки; методи аналізу; формалізовані методи; неформалізовані методи.

Рис.: 2. Бібл.: 6.

В статье исследованы сущность, содержание и составляющие элементы планирования развития субъектов реального сектора экономики, определены место и роль анализа и оиенки риск-среды в процессе планирования развития, систематизированы основные методы ее анализа и оценки. Проведенное исследование позволяет сделать выводы о необходимости анализа и оченки риск-среды, что способствует повыпению эффективности реализачии стратегических и тактических планов в прочессе планирования развития субъектов реального сектора экономики.

Ключевые слова: планирование развития; риск-среда; реальный сектор экономики; методы анализа; формализованные методы; неформализованные методы.

Рис.: 2. Библ.: 6.

JEL Classification: L6

Target setting. Globalization and integration processes taking place in the global economy cause the need for adaptation of the real sector of the national and regional economy subjects to changing conditions of management. This is due to the transformation of the sectoral structure of social production (the rapid emergence of new productions and activities and the disappearance / transformation of those previously defined the specialization of the economy); the redistribution of markets and the growing struggles for resources, especially those that are not reproducible; fluctuations in customer demand for products, change in the role of the human factor, the transition of economic entities to the international format; development of IT technologies, informatization of the economy and obtaining additional opportunities for business, including those that facilitate work and accelerate the pace of its implementation. These and other trends determine the formation of new approaches to the planning of the development of entities in the real sector of the economy, which must flexibly respond to the uncertainty of the risk environment. 
ТЕОРЕТИЧНІ ПРОБЛЕМИ РОЗВИТКУ НАЦІОНАЛЬНОЇ ЕКОНОМІКИ

Subjects of the real sector of a housekeeper play a key role in the development of any country and serve as the foundation for its socio-economic growth. The real sector of the economy combines business entities that produce tangible and intangible goods, whose activities lead to the creation of gross domestic and gross national product, as well as national income [6, p. 9-10].

The functioning of any entities under modern conditions of economic activity is closely related to the emergence of risk situations that can lead to unwanted changes in the sources of formation and the use of financial resources, as well as to negative trends in the process of forming its interim and final financial results, in including loss of profit / income / equity. Thus, the urgency of the problem of the analysis and assessment of the risk environment in the context of planning the development of entities in the real sector of the economy does not raise any objections.

Actual scientific researches and issues analysis. The urgency of the problems of planning the development of the subjects of the real sector of the economy causes a high scientific interest in their research by numerous domestic and foreign scientists, such as: Acoff R., Afanasyev M. V., Butov G. N., Drapkin G. S., Zin E. A., Lavriv L. A., Meskon M., Moskaluk V. E., Tarasyuk G. V., Shvab L. I., Yastremskaya O. M. etc. Methodological problems of the analysis and assessment of the risk environment in the context of the functioning and development of economic entities is the focus of I. A. Blanca, M. V. Chekulaev, A. A. Lobanova, A. G. Gryaznov, A. O. Starostina, A. B. Chugunov and many other scholars.

Uninvestigated parts of general matters defining. Despite the presence of a significant number of publications devoted to these issues, the problems of increasing the effectiveness of planning for the development of business entities require further research, in particular in the aspect of the analysis and assessment of risk environment.

The research objective. The purpose of the article is to study the methodological aspects of the analysis and assessment of the risk environment in the process of planning the development of entities in the real sector of the economy.

The statement of basic materials. Planning of the development of the subjects of the real sector of the economy is a process of formation and substantiation of strategic and tactical goals and tasks, selection of optimal directions of their achievement in accordance with available resources, aimed at increasing the efficiency of work in the future. Strategic planning sets the target and the main directions of further development of the business entity by developing its strategy, taking into account the life cycle and competitive environment, and creates a basis for all management decisions.

The strategic plan of development formulates the key goals and objectives of the enterprise for the long-term period, which should be coordinated with the general strategy of development of the subject of the real sector of the economy.

Tactical planning is characterized by a higher level of detail and focused on how to implement strategic goals, taking into account financial, resource, informational, political, legal, time and other constraints.

Planning of the development of the subjects of the real sector of the economy is aimed at solving the following main tasks: assessment of expediency and necessity of functioning and development taking into account the stage of the life cycle of the subject of management; increase of stability, investment attractiveness and optimization of resources attraction for realization of development projects; reduction of operational, investment and financial risks; improvement of the price, marketing and assortment policy and study of existing capacity and prospects of development of markets; definition of the prospects of activity on the basis of the system of quantitative and qualitative development parameters taking into account the change of risk environment, etc. 
ТЕОРЕТИЧНІ ПРОБЛЕМИ РОЗВИТКУ НАЦІОНАЛЬНОЇ ЕКОНОМІКИ

Since any enterprise operates in conditions of uncertainty and different degree of probability of occurrence of certain risks, the external and internal environment can be defined as the risk environment of the subject of the real sector of the economy. It should be noted that the risk environment of the subject of the real sector of the economy can be represented by macro, meso and micro levels. Macro- and mezo-valences are related to the external environment and are represented respectively by the medium of the indirect (indirect) and immediate surroundings. The internal environment is embodied in the potential of the subject of economic activity and is considered at the micro level (Fig. 1).

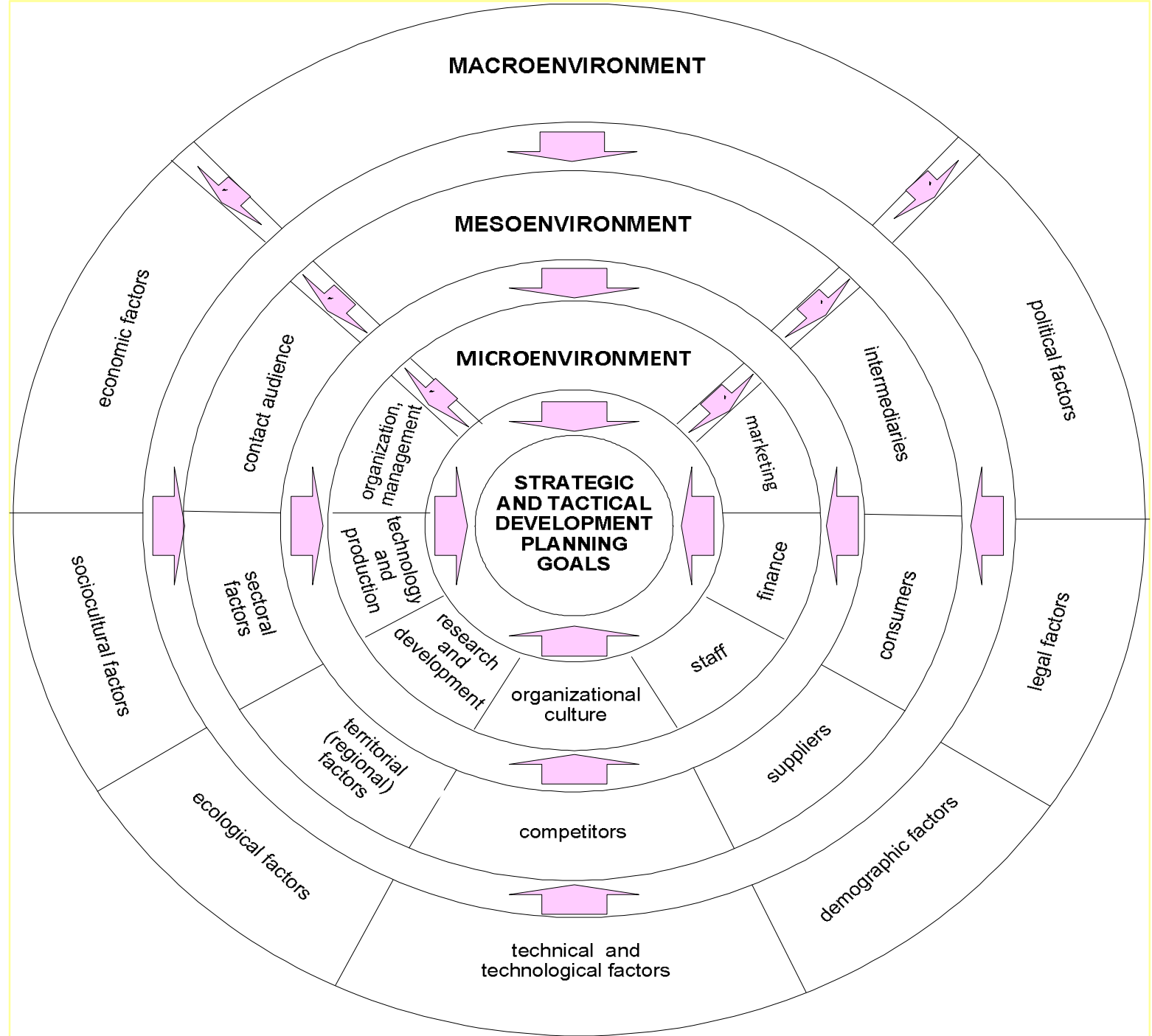

Fig. 1. Risk-environment of subjects of the real sector of the economy

Source: constructed by authors on the basis of $[4 ; 6]$.

To the factors of the macroenvironment, which determine the planning of the development of the subject of the real sector of the economy of the enterprise, we shall attribute:

- economic (the stage of the cycle of economic development, the general state of the economy of Ukraine, including the potential of the real sector, the development of integration processes in the economic space, general and sectoral conjuncture, methods and mechanisms of regulation, competitiveness and investment attractiveness of economic entities, investment climate, regulation of export and import of products on the basis of licensing and quotation, change of customs policy, etc.); 
ТЕОРЕТИЧНІ ПРОБЛЕМИ РОЗВИТКУ НАЦІОНАЛЬНОЇ ЕКОНОМІКИ

- technical and technological (state and dynamics of scientific and technological progress, the level of technology and technology, the degree of use of innovations, the flexibility of production processes, the productivity and reliability of equipment, the availability of developed infrastructure, etc.);

- socio-cultural (social protection by means of legally established rights, creation of new workplaces, organization of the system of subsidies and benefits, stability of wages, increase of the level of social protection, degree of development of culture and education of society, etc.);

- legal (perfection and stability of the normative base, including in the field of taxation, licensing, patenting, etc.);

- political (general political climate and the state of development of international relations, the role and place of the country in the political arena, the policy of foreign countries regarding socio-economic and political reforms in Ukraine, military-political conflicts in separate regions of the country and the world);

- demographic (the formation of labor resources (fertility, mortality and natural population growth), the variability of generations of working population, life expectancy, migration of the population, etc.);

- environmental (requirements of environmental legislation, costs arising from the utilization of waste from production, maintenance and operation of environmental protection and treatment facilities, etc.).

Factors of the mesoenvironment that affect the process of planning the development of the subject of the real sector of the economy are:

- sectoral (industry, sectoral planning and economic stimulation, regulatory framework, control system, level of competition in the industry, introduction of innovations, etc.);

- regional (natural conditions and resources, ecological properties of the territory, the state of infrastructure development (production, social, scientific and technical, environmental, intellectual));

- a contact audience (state control and regulation bodies (Ministry of Finance, State Fiscal Service), executive bodies, press and news agencies, financial advisers, audit firms, lawyers, trade unions, etc.);

- - suppliers (price and quality of raw materials, spare parts, etc., terms of delivery, delivery time, service, etc.);

- consumers of products (price and quality of products (works, services), conditions of sale, warranty and post-warranty service, etc.);

- competitors (the study of which involves taking into account the size of the market, the extent of competition, the number of firms-buyers and the volume of procurement, the availability of substitutes products, etc.);

- intermediaries in the financial market (banking institutions and specialized financial and credit institutions (insurance companies, pension funds, financial companies, etc.), commodity markets (commodity exchanges, brokerage companies, etc.) and the labor market (employment services, staffing agencies, etc.); etc.).

The factors of the microenvironment of the subject of the real economy sector should be considered: management organization, technology and production, research and development, marketing, personnel, finance, organizational culture. That is, the microenvironment factors characterize the structure and efficiency of the enterprise management system, the level of organization of its marketing and financial and economic activity, the nature of the organization of labor and production processes, the degree of effectiveness of strategic and tactical planning and forecasting systems created at the enterprise, the image of the enterprise, monitoring and prompt response to risks the environment and so on. 
ТЕОРЕТИЧНІ ПРОБЛЕМИ РОЗВИТКУ НАЦІОНАЛЬНОЇ ЕКОНОМІКИ

The influence of these factors can cause both the emergence of risks and the negative or positive dynamics of their changes. Note that the risks posed by macroeconomic factors (financial, market, investment, innovation, currency, tax, inflation, etc.) and mise environments (price, commodity, interest, currency, innovation, investment, stock, credit, etc.) are predominantly unmanaged, however, it is possible to minimize the negative impact of the identified risks by taking appropriate actions at the micro level, namely by diversifying activities, production and sales, limiting costs, insurance and reinsurance, transferring risks, that is, so that $\mathrm{b}$ to use the most favorable opportunities and minimize the influence of destructive factors.

The risks of the microenvironment (financial stability, liquidity, business activity, credit, interest, price, innovation, etc.) of the real sector of the economy are able to manage in the presence of an effective system of risk management, which involves the identification, analysis and risk assessment. Risk identification is preceded by risk-environment research, which allows determining the likelihood of occurrence of risk events and assessing the degree of risk exposure to the implementation of the strategic and tactical objectives of the entity.

The analysis and assessment of the risk environment is carried out using certain methods (Fig. 2), which are a system of theoretical and cognitive categories, scientific instruments and regulatory principles for studying the risks of planning, functioning and development of the subjects of the real sector of the economy [5].

In the structure of general scientific and specific scientific methods and models, the dialectic method assumes that economic phenomena must be considered in interconnection, movement and development [5].

Considering any economic entity of the real sector of the economy can be as a complex, dynamic system, which is characterized by: purposefulness, hierarchy (the presence of structural components, the division of functions, definition of rights and levels of subordination), polystructure (simultaneous existence of the enterprise of interconnected subsystems ( shops, sections, services, departments, etc.), openness (manifested in the close interaction of the enterprise with the environment).

The application of the dialectical method allows to detail the development of the subjects of the real sector of the economy as a system, to identify and study the interrelations between the elements of the investigated system and the causal relationships of change in their parameters, to measure the degree of influence of factors on the change in the parameters of the economic system and the overall result of their actions, develop a system of indicators that fully characterize the processes of functioning and development; to evaluate analytical results and to substantiate the conclusions and recommendations.

The number of existing methods of research determines the need for their scientific classification, according to which all methods are distributed to non-formalized and formalized. Unformalized - based on the description of analytical procedures at the logical level, formalized - are based on sufficiently defined formalized analytical dependencies.

The development of business entities is directly related to the strategic changes that are made through the planning system. The effectiveness of the planning system is determined by the achievement of the established tactical and strategic goals and the provision of competitive advantages through the realization of existing opportunities and the neutralization of the risks of the environment. In order to evaluate the effectiveness of the strategic planning system at the enterprise, it is necessary to form a system of financial and non-financial, quantitative and qualitative indicators that would fully reflect the changes related to the implementation of strategic and tactical plans for development that requires further research. 


\section{METHODS OF ANALYSIS AND ASSESSMENT OF RISK ENVIRONMENT}

1. Non-formalized methods - based on the description of analytical procedures at the logical level

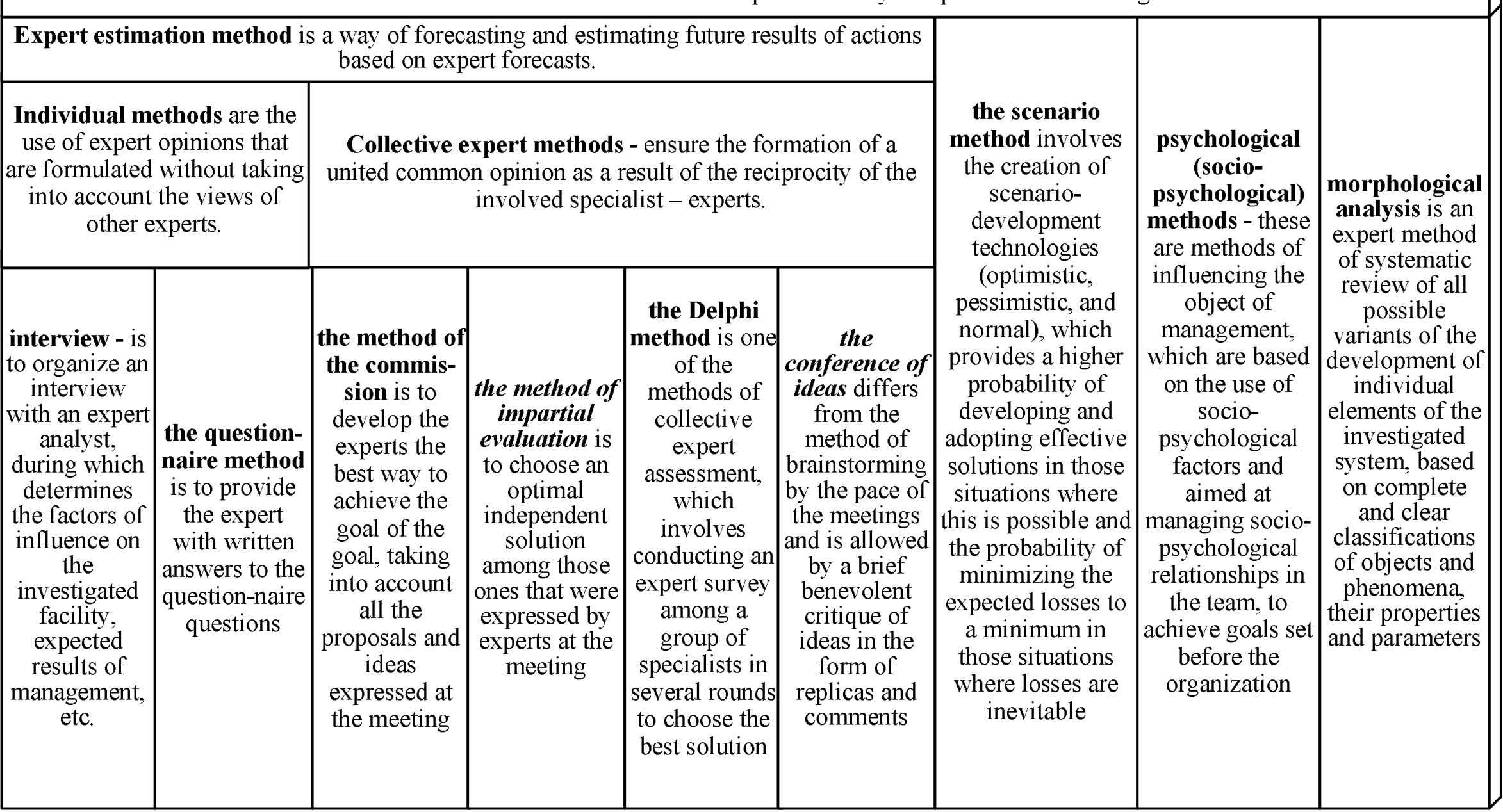

Fig. 2. Formalized and non-formalized methods of risk-environment analysis and evaluation 


\section{METHODS OF ANALYSIS AND ASSESSMENT OF RISK ENVIRONMENT (continuation)}

2. Formalized methods are based on sufficiently defined formalized analytical dependencies. These methods can be divided into two groups: economic and mathematical methods and economic and statistical methods

Economic and mathematical methods are aimed at solving such analytical tasks as: stochastic factor analysis, optimization of indicators, complex estimation

\begin{tabular}{|c|c|c|c|c|c|}
\hline \multicolumn{4}{|c|}{ tactor } & \multicolumn{2}{|c|}{$\begin{array}{c}\text { development } \\
\text { de }\end{array}$} \\
\hline $\begin{array}{l}\text { mathematical and } \\
\text { statistical methods } \\
\text { (correlation analysis, } \\
\text { regression analysis, } \\
\text { cluster analysis, etc.) }\end{array}$ & $\begin{array}{c}\text { econometric methods } \\
\text { (matrix methods, spectral } \\
\text { analysis, inter-industry } \\
\text { balance theory, etc.) }\end{array}$ & $\begin{array}{c}\text { methods of economic } \\
\text { cybernetics and } \\
\text { optimal programming } \\
\text { (mathematical, linear } \\
\text { and dynamic } \\
\text { programming of system } \\
\text { analysis) } \\
\end{array}$ & $\begin{array}{c}\text { methods of research } \\
\text { of operations and } \\
\text { the theory of } \\
\text { decision-making } \\
\text { (mass service theory, } \\
\text { graph theory, game } \\
\text { theory, etc.) } \\
\end{array}$ & \begin{tabular}{|} 
general statistical \\
methods (grouping, \\
mean and relative \\
values, dynamic series, \\
graphic method and \\
selective observation)
\end{tabular} & \begin{tabular}{|c|} 
methods of elimination \\
which include the \\
method of chain \\
substrates, absolute, \\
those relative \\
differences, logarithm, \\
index method, etc. \\
\end{tabular} \\
\hline in particular & in particular & in particular & in particular & in particular & in particular \\
\hline 2 & 25 & 叉 & $\sum$ & $\sum$ & 叉 \\
\hline $\begin{array}{c}\text { correlation } \\
\text { analysis - a } \\
\text { statistical study of } \\
\text { the relationship } \\
\text { between random } \\
\text { variables aimed at } \\
\text { identifying existing } \\
\text { significant } \\
\text { dependencies of } \\
\text { one variable from } \\
\text { others }\end{array}$ & $\begin{array}{l}\text { represented by the model, } \\
\text { which includes the theory } \\
\text { of interbranch balance, } \\
\text { proceeds from the } \\
\text { possibility of achieving the } \\
\text { general macroeconomic } \\
\text { equilibrium, which is } \\
\text { represented by a model that } \\
\text { includes the structural } \\
\text { interrelation of all stages of } \\
\text { the production process }\end{array}$ & $\begin{array}{c}\text { mathematical } \\
\text { programming is a } \\
\text { method of studying } \\
\text { processes or } \\
\text { phenomena by creating } \\
\text { their mathematical } \\
\text { models and studying } \\
\text { these models }\end{array}$ & $\begin{array}{c}\text { the theory of mass } \\
\text { service - a theory that } \\
\text { studies statistical } \\
\text { laws in mass } \\
\text { operations, which } \\
\text { consist of a large } \\
\text { number of } \\
\text { homogeneous } \\
\text { elementary } \\
\text { operations }\end{array}$ & $\begin{array}{l}\text { grouping is a means of } \\
\text { distributing entities on a } \\
\text { homogeneous basis of } \\
\text { elements used in the } \\
\text { analysis, for example, to } \\
\text { disclose the content of } \\
\text { average aggregates and } \\
\text { the influence of } \\
\text { individual units on these } \\
\text { mean }\end{array}$ & $\begin{array}{c}\text { the index method } \\
\text { makes it possible to } \\
\text { determine the degree of } \\
\text { influence of individual } \\
\text { factors on the overall } \\
\text { result }\end{array}$ \\
\hline & & & & & \\
\hline
\end{tabular}

Source: built by authors based on $[1 ; 2 ; 5 ; 6]$.

Economic-statistical methods are used for the

study of mass phenomena, processes, facts and study of mass phenomena, processes, facts and general statistical methods (grouping ean and relative (ues, dynamic series, graphic method and lective observation) d of chain strates, absolute, regression analysis,

$$
\text { Fig. 2. Page } 2
$$


ТЕОРЕТИЧНІ ПРОБЛЕМИ РОЗВИТКУ НАЦІОНАЛЬНОЇ ЕКОНОМІКИ

Conclusions. The analysis and assessment of the risk environment by means of the above methods will allow any entity to: maintain an optimal level of risk that is incapable of causing critical and catastrophic consequences (ie, lead to loss of income and capital), control and regulation of the risks of emerging risk in crisis conditions of management. The above will allow to objectively and comprehensively estimate level of display of a degree of risks and accordingly to minimize them taking into account changing of conditions of macro, meso and microenvironment. Prospects for further research are to create a system of balanced indicators that would quantitatively and qualitatively assess the impact of the risk environment on the implementation of strategic and tactical plans for the development of entities in the real sector of the economy.

\section{References}

1. Butnyk, O. M. (2003). Vnutrishnia mihratsiia ta tymchasovi peremishchennia v Ukraini v umovakh politychnykh ta sotsialno-ekonomichnykh zahroz [Economic-mathematical modeling of the dynamic laws of the development of economic systems]. Kharkiv: INZhEK [in Ukrainian].

2. Kalchenko, O. M., Shyshkina, O. V. (2018). Finansovyi analiz [Financial analysis]. Chernihiv: Vydavets Brahynets O. V. [in Ukrainian].

3. Spitsnandel, V. N. (2000). Osnovy sistemnogo analiza [Fundamentals of System Analysis]. Saint Petersburg: Business Press [in Russian].

4. Tompson, A. A. \& Striklend, A. Dzh. (2009). Strategicheskii menedzhment. Kontseptsii i situatsii dlia analiza [Strategic Management. Concepts and situations for analysis]. (12 ${ }^{\text {nd }}$ ed.). (Trans). Kiev: Viliams [in Russian].

5. Kim, Dzh. O., Myuller, Ch. U. \& Klekka, U R. (1989). Faktornii, diskriminantnyi i klasternyi analiz [Factorial, discriminant and cluster analysis]. Moscow: Finansy i statistika [in Russian].

6. Ilchuk, V. P. (Eds.). (2017). Finansove zabezpechennia rozvytku subiektiv pidpryiemnytstva realnoho sektoru ekonomiky [Financial support for the development of business entities in the real sector of the economy]. Chernihiv: CNUT [in Ukrainian].

\section{References (in language original)}

1. Бутник О. М. Економіко-математичне моделювання динамічних закономірностей розвитку економічних систем: монографія. Харків: ІНЖЕК, 2003. 224 с.

2. Кальченко О. М., Шишкіна О. В. Фінансовий аналіз: навчальний посібник. Чернігів: Видавець Брагинець О. В., 2018. 524 с.

3. Спицнандель В. Н. Основы системного анализа. Санкт-Петербург: Бизнес-пресса, 2000. 326 с.

4. Томпсон-мл., А. А., Стрикленд А. Дж. ІІІ. Стратегический менеджмент. Концепции и ситуации для анализа: [перевод с английского]. 12-е изд. Москва; Санкт-Петербург; Киев: Вильямс, 2009. 924 с.

5. Факторний, дискриминантный и кластерный аналіз: пер. с англ. / Дж.-О. Ким и др. Москва: Финансы и статистика, 1989. 215 с.

6. Фінансове забезпечення розвитку суб'єктів підприємництва реального сектору економіки: колективна монографія / за заг. ред. В. П. Ільчука. Чернігів: ЧНТУ, 2017. 272 с.

Shyshkina Olena - PhD in Economics, Associate Professor, Associate Professor of Department of Finance, Banking and Insurance, Chernihiv National University of Technology (95 Shevchenka Str., 14035 Chernihiv, Ukraine).

Шишкіна Олена Вікторівна - кандидат економічних наук, доцент, доцент кафедри фінансів, банківської справи та страхування, Чернігівський національний технологічний університет (вул. Шевченка, 95, м. Чернігів, 14035, Україна).

Шишкина Елена Викторовна - кандидат экономических наук, доцент, доцент кафедры финансов, банковского дела и страхования, Черниговский национальный технологический университет (ул. Шевченко, 95, г. Чернигов, 14035 , Украина)

E-mail: shyshkina.olena.v@gmail.com

ORCID: http://orcid.org/0000-0002-8946-1027

Kalchenko Olga - PhD in Economics, Associate Professor, Associate Professor of Department of Finance, Banking and Insurance, Chernihiv National University of Technology (95 Shevchenka Str., 14035 Chernihiv, Ukraine).

Кальченко Ольга Миколаївна - кандидат економічних наук, доцент, доцент кафедри фінансів, банківської справи та страхування, Чернігівський національний технологічний університет (вул. Шевченка, 95, м. Чернігів, 14035, Україна).

Кальченко Ольга Николаевна - кандидат экономических наук, доцент, доцент кафедры финансов, банковского дела и страхования, Черниговский национальный технологический университет (ул. Шевченко, 95, г. Чернигов, 14035, Украина).

E-mail: Onkalchenko.2014@gmail.com

ORCID: http://orcid.org/0000-0002-7120-9843

Shyshkina, O., Kalchenko, O. (2018). Methodological principles of the analysis and risk assessment of the environment in the process of planning the development of real economy sector subjects. Problems and prospects of economics and management, 2 (14), 24-31. 